\title{
Environmental Variables and Tree Population Structures in Deciduous Forests of Central Brazil with Different Levels of Logging
}

\author{
Daniel Luis Mascia Vieira ${ }^{1,2 *}$ and Aldicir Scariot ${ }^{3,4}$ \\ ${ }^{1}$ Embrapa Tabuleiros Costeiros; Av. Beira Mar, 3250; Jardins; 49025-040; dvieira@cpatc.embrapa.br; Aracaju - \\ SE - Brasil. ${ }^{2}$ Pós-Graduação em Ecologia; Universidade de Brasília; C. P. 04457; 70919-970; Brasília - DF - \\ Brasil. ${ }^{3}$ United Nations Development Programme; SCN quadra 2; bloco A, Ed. Corporate Financial Center; $7^{o}$ \\ andar, 70712-901; Brasília - DF - Brasil. ${ }^{4}$ Laboratório de Ecologia e Conservação; Embrapa Recursos Genéticos e \\ Biotecnologia; C. P. 02372; 70770-900; Brasília - DF - Brasil
}

\begin{abstract}
Population structures of six tree species in three fragments of intact seasonal deciduous forest and three fragments disturbed by logging were studied in the northeastern Goiás. Forty random $400 \mathrm{~m}^{2}$ plots were allocated in each fragment to survey plant population structures, number of stumps, cattle feces, burnt logs, and canopy openness. Soil cover by life forms was estimated in $1 \mathrm{~m}^{2}$ sub-plots. Lianas were abundant in intermediately logged fragments and invasive herbs in the most disturbed fragment. Cattle avoided dense herbaceous strata, such as liana tangles. Cavanillesia arborea, Eugenia dysenterica and Swartzia multijuga trees occurred at very low densities in all the fragments and their seedlings were practically absent, which might endanger their future populations in these fragments. Myracrodruon urundeuva, Tabebuia impetiginosa and Astronium fraxinifolium, the most logged species, had high density of seedlings in all the fragments. However, the highest density of saplings and juvenile individuals occurred in the most disturbed fragment.
\end{abstract}

Key words: Seasonal forest; canopy openness; plant cover; cattle grazing; lianas

\section{INTRODUCTION}

Selective logging causes soil compaction (Whitman et al., 1997; Frederiksen and Pariona, 2002) and soil disturbance (Frederiksen and Mostacedo, 2000; Fredericksen and Pariona, 2002). It damages trees and saplings in logged stands (Webb, 1997; Jackson et al., 2002) and also increases canopy openness (Uhl and Vieira, 1989; Veríssimo et al., 1992; Webb, 1997). Changes in canopy openness can promote regeneration of species that are present in seed, seedling and juvenile banks (Bawa and Seidler, 1998; Pinard et al., 1999a; Fredericksen and Mostacedo, 2000). This may favor some species to the detriment of others, and may alter species composition in the logged forest (Kuusipalo et al., 1996; Bawa and Seidler, 1998; Kammesheidt, 1998; Webb, 1998). Lianas, herbs and pioneer trees are benefited by high canopy openness, frequently preventing the regeneration of other species (Chapman and Chapman, 1997; Kammasheidt, 1998; Fredericksen et al., 2000).

The understanding of how plant regeneration is affected by changes in the environmental factors in logged areas contributes to the development of

\footnotetext{
${ }^{*}$ Author for correspondence
} 
management techniques that may help diversity recovery. It may also contribute to increase regeneration of high-value timber species (Guariguata and Pinard, 1998; Pinard et al., 1999b; Fredericksen and Mostacedo, 2000). Logged forests have recently been recognized as important for biodiversity conservation (Johns, 1988; Chazdon, 1998; Pinard et al., 1999b) and for the functionality of ecosystems (Pinard and Putz, 1996), since few forest remnants are left in many ecosystems, and many of those are usually disturbed (Chazdon, 1998).

Dry forest is the most threatened tropical terrestrial ecosystem (Janzen, 1988; Khurana and Singh, 2001; Sanchez-Azofeifa et al., 2005) and one of the least known (Janzen, 1988, Vieira and Scariot, 2006a). In Central Brazil, it occurs in patches within the Cerrado biome. The Paranã River basin (northeastern Goiás state and Southeastern Tocantins state) has large patches of highly fertile soils, where these forests occur (Ratter, 1992). However, seasonally deciduous forests of the flat lands cover only $5 \%$ of their originally occupied area (Andahur, 2001), which is a consequence of deforestation for pasture (IBGE, 1995; Scariot and Sevilha, 2000; 2005). In addition, most of the remaining forested areas have been logged and disturbed by fire and cattle grazing (Scariot and Sevilha, 2005).

In this study, the population structure of six tree species was analyzed in six forest fragments, three of which were intact and three were selectively logged. Three studied species have high timber value and three produce fruits and seeds for wildlife. Environmental variables that characterize disturbance intensity caused by logging, fire and cattle were estimated. The following questions were addressed: (i) How were environmental factors affected by selective logging? (ii) How were population structures of the target species affected by logging? Then, environmental factors were indirectly related to the regeneration of the studied species.

\section{Study Area}

The study was carried out in the Paranã river basin $\left(13^{\circ} 20^{\prime}-15^{\circ} 40^{\prime} \mathrm{S}, 46^{\circ} 35^{\prime}-47^{\circ} 30^{\prime} \mathrm{W}\right)$, at the municipality of São Domingos, in northeastern Goiás state. This region presents a vegetational mosaic, and has some of the last remnants of seasonally deciduous forests in Brazil. The forest occurs at altitudes of 400-600 m, with annual precipitation of $1236 \mathrm{~mm} \pm 255$ ( $\mathrm{SD}$, data from
1969 to 1994), of which $89 \%$ falls between October and March. The mean annual temperature is $23^{\circ} \mathrm{C}$ and is fairly constant throughout the year. The landscape is flat and consists of limestone geology, with occasional limestone outcrops containing a fairly distinct tree flora (Silva and Scariot, 2003; 2004a, 2004b). Soils are mostly nitosols with a clayey texture (IBGE, 1995; Scariot and Sevilha, 2005; following Embrapa, 1999).

On the flat lands, the forest canopy is $17-23 \mathrm{~m}$ in height with a basal area of $23-28 \mathrm{~m}^{2} /$ ha (unlogged areas; Scariot and Sevilha, 2005). There are over 100 tree species, which are usually found in large Brazilian biomes such as Cerrado, Caatinga, Amazonia and Atlantic Forest (Scariot and Sevilha, 2005). Cattle farms, logging, and incipient agriculture are the main economic activities of the region. Wood has been mainly harvested for corral and fence building, for the production of woodchip, and for civil construction. The main exploited species are Astronium fraxinifolium Schott, Myracrodruon urundeuva Fr. All., Schinopsis brasiliensis Engl. and Tabebuia impetiginosa (Mart. ex DC.) Standl., which have been commercialized locally, regionally and in Southern Brazilian markets (IBGE, 1995).

\section{Methods}

Study sites - Three forest fragments without evidence of logging (named Intact: I1, I2 and I3) and three fragments with different logging intensities and ages were selected (named Logged: L1, L2 and L3). The fragments varied from 60200ha and were distant of each other from a few meters up to $5.5 \mathrm{~km}$. Logged 1 had been selectively logged aproximately 18 years before the study. Logged 2 and L3 had been intensively logged five years before the study. Logged 3 had also suffered accidental fire some months after logging. There were no records of fire in the other fragments over the past 10 years. Landowners avoid reporting the harvested wood volume and the minimum diameter of the harvested trees, either because forest management has been illegally done or because they do not have records of the logging activities. Cattle forage in the fragments (approximately $0.5 \mathrm{cows} / \mathrm{ha}$ ) during the late dry season and early rains, when the planted pastures are dry.

Study species - A. fraxinifolium, M. urundeuva (Anacardiaceae), and T. impetiginosa (Bignoniaceae) are among the most valuable and 
harvested tree species in northeastern Goiás State (IBGE, 1995). Eugenia dysenterica DC. (Myrtaceae) and Swartzia multijuga Vogel (Fabaceae) produce fleshy fruits, and like dryfruited Cavanillesia arborea (Willdenow) K. Schum. (Bombacaceae), their seeds are highly consumed by wildlife (Vieira and Scariot, 2006b). Eugenia dysenterica occupies the midstory and the other species occupy the canopy layer.
Sampling and measurements - Parallel trails were made every $100 \mathrm{~m}$, perpendicular to the longest side of the fragments. In each fragment $4020 \mathrm{x}$ $20 \mathrm{~m}$ sample units (SUs) were randomly established along the trails, with sub-sample units of $5 \times 5 \mathrm{~m}$ and $2 \times 2 \mathrm{~m}$. Canopy openness was estimated with a spherical densiometer (Lemmon, 1957).

Table 1 - Diameter classes $(\mathrm{cm})$ corresponding to development classes of studied species. The individuals $<5 \mathrm{~cm}$ (DBH) were measured at the base of the plant, while larger individuals were measured at the breast height.

\begin{tabular}{lllll} 
& Seedling & Sapling & Juvenile & Adult \\
\hline Myracrodruon & $<0.2$ & $0.2-1$ & $1-05$ & $\geq 15$ \\
Tabebuia & $<0.2$ & $0.2-1$ & $1-05$ & $\geq 30$ \\
Astronium & $<0.2$ & $0.2-1$ & $1-05$ & $\geq 15$ \\
Cavanillesia & $<1.0$ & $1.0-5$ & $5-50$ & $\geq 50$ \\
Eugenia & $<0.2$ & $0.2-1$ & $1-05$ & $\geq 05$ \\
Swartzia & $<0.2$ & $0.2-1$ & $1-05$ & $\geq 15$ \\
\hline
\end{tabular}

The SU was subdivided into four $10 \times 10 \mathrm{~m}$ quadrants and the estimation was taken at the center of each quadrant in four orthogonal directions. In each SU, feces and cattle trails were counted in order to estimate pasturing and trampling intensity by the cattle (Relva and Veblen, 1998). Stumps were counted in order to estimate logging intensity in the fragments. Dead individuals $>5 \mathrm{~cm}$ (diameter at the breast height, $\mathrm{DBH}$ ) were counted. Data were collected from December 2000 to January 2001, at the middle of the rainy season.

Soil cover up to $1 \mathrm{~m}$ in height was estimated by the life forms classified into (i) trees, (ii) lianas, (iii) herbaceous-shrubs, and (iv) invasive herbs. A $1 \mathrm{x}$ $1 \mathrm{~m}$ metal frame subdivided into $10010 \mathrm{x} 10 \mathrm{~cm}$ quadrants was used for the survey at the corner of the SUs. The number of occupied quadrats was recorded. Also, the number of occupied quadrats by every life form was recorded (modified from Kent and Coker, 1994). This method allowed more than one life form occupy the same quadrat. If a plant had only covered part of the cell, it was recorded. Invasive herbs were considered plants that did not naturally occur in the forests, although they can be abundant in pastures surrounding the fragments. Herbaceous-shrub species were plants that occupy the understory.

In the $20 \times 20 \mathrm{~m}$ SUs, individuals $\geq 5 \mathrm{~cm}(\mathrm{DBH})$ were measured. In the $5 \times 5 \mathrm{~m}$ sub-sample units, individuals $\geq 1 \mathrm{~cm}$ (diameter at the base of the plant $(\mathrm{DBP})$ ) up to $5 \mathrm{~cm}(\mathrm{DBH})$ were measured at the base of the plant. Individuals $\leq 1 \mathrm{~cm}$ (DBP) were measured in the $2 \times 2 \mathrm{~m}$ sub-sample units. Individuals were classified into seedling, sapling, juvenile and adult (Table 1), based on data from germination and seedling growth in the nursery and field observations. Seedlings were considered individuals that germinated in the same rainy season of the survey. Seeds of these species placed to germinate at the beginning of the rainy season (September-October) reached up to $2 \mathrm{~mm}$ (DBP) in January (period of the survey). Only for Cavanillesia, the seedlings were $\leq 10 \mathrm{~mm}$ (DBP). Saplings were considered those individuals that germinated in earlier rainy seasons and that were exposed to environmental factors for at least one year. Juveniles were individuals in the intermediate category between saplings and adults. Adults were individuals in the reproductive stage. Data analysis - In order to describe the relationship among environmental variables and life forms, an exploratory analysis was carried out using PCA ( R mode). Also, the PCA (Q mode) was carried out to ordinate the SUs, according to the factors generated from environmental variables (Tabachnick and Fidell, 2001). Data of the all variables were transformed by adding 0.5 and then square rooting in order to approximate normal distribution and reduce heteroscedasticity (Zar, 1999). 
To contrast canopy openness, soil cover and population structures between logged and intact fragments, data from all intact fragments were grouped; generating the Intact category $(n=120)$. This arrangement best represented the traits of intact fragments, reducing the effect of peculiarities not related to the disturbance conditions focused in this study. Besides, the comparison of each fragment would result in an excessive number of post hoc comparisons. Logged fragments were very different in disturbance history, therefore they were not grouped.

Canopy openness estimates within the SUs were averaged among the four quadrants, resulting in 40 measures of canopy openness for each fragment. The frequency distributions of canopy openness in the three combined intact fragments (Intact) were compared with each of the three logged fragments, using the Kolmogorov-Smirnov test for two samples (Siegel, 1975). Bonferroni`s correction was used for the three comparisons; $P \leq 0.05 \times 3^{-1}$ $=0.017$. Soil cover for each life form and total cover was compared between the logged fragments and Intact using the Kruskal-Wallis test. This was done because percentage data had very asymmetrical frequency distribution, with frequent zero values and heteroscedasticity (Zar, 1999). Whenever significant differences were found, Dunn test $(Q)$ (Zar, 1999) was used to compare each logged fragment with the combination of the intact ones (Intact). The use of Bonferroni's correction was unnecessary, because $Q$ test considers the number of comparisons.

Population structures were analyzed for each species. The null hypothesis that there were no differences in the proportion of individuals in the development classes among the fragments (logged versus Intact) was tested. If significant differences were detected, each logged fragment was compared with Intact. Although the total densities were not analyzed (only proportions), they were considered in the results and discussion. The Likelihood Ratio Chi-Square test $\left(G^{2}\right)$ was used when the observed and expected frequencies satisfied its assumptions. Data violating the assumptions were analyzed through the simulation of the $G^{2}$ statistics. This method generated an empirical distribution of the statistics for the data set. The procedure generated 10,000 random tables with the same marginal totals as in the original table, and the statistical tests for each of them were computed. Finally, the probability of occurrence of
$G^{2}$ statistics equal or greater than those in the observed table was verified (Zelterman, 1999). Bonferrroni's correction was used for the three $a$ post hoc comparisons; $P \leq 0.05 \times 3^{-1}=0.017$. The Statistica package (Statsoft, 2000) was used to run analysis, except for population structure data run in the SAS (SAS, 1999).

\section{RESULTS}

Environmental variables and soil cover - The PCA factor 1 of environmental variables and soil cover explained $26.5 \%$ of the variance, while the second factor explained only $14.0 \%$. Canopy openness had the most contribution to the factor 1 (Fig. 1a). The number of stumps and dead trees was weakly related to the canopy openness (Fig. 1a). Canopy openness of intact fragments was significantly smaller and less variable (mean $=12 \%$; range: 3 $22 \%$ ) than in the logged fragments (mean $=43 \%$, range: $7-95 \%$, Fig. 2), (K-S, P $<0.001$ for the comparisons of Intact with L1, L2 and L3). Canopy openness constituted a gradient among the logged fragments (L1 to L3; Fig. 2). Cattle feces were found in high density in all fragments, but were related to plots with lower canopy openness, where plant cover was low (Fig. 1a). Cattle trails made the largest negative contribution to PCA factor 1 (Fig. 1a).

Sample units of the six fragments were distributed along the factor 1 of environmental variables in a gradient, where most L3 SUs had the largest positive values (Fig. 1b). Logged 2 had similar tendencies, but with smaller values. Logged 1 had intermediate values between the most disturbed and the intact fragments, with the latter showing similar and negative values (Fig. 1b).

Soil cover by life forms varied significantly among the fragments (Fig. 3). The total soil cover was directly related to canopy openness (Fig. 1a), which meant that L3 and L2 had the highest soil cover (Fig. 3). Cover by lianas increased with disturbance, with L1 and L2 having larger percentages than Intact, although this did not happen in L3. Invasive herbs rather than lianas increased significantly in L3, and this was strongly related to canopy openness (Fig. 1a). Herbaceousshrub cover was associated with low canopy openness (Fig. 1a), and it was higher in intact fragments and in L1 than in the more disturbed areas (Fig. 3). 

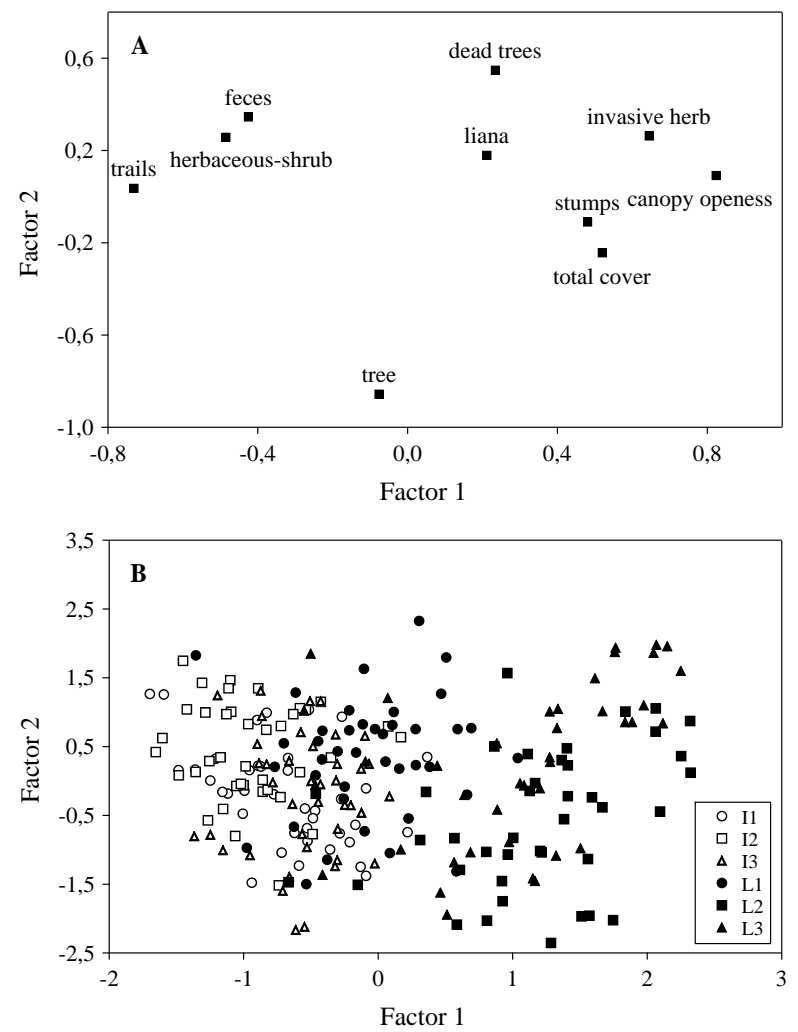

Figure 1 - Plot of Factor 1 and Factor 2 of the Principal Component Analysis (PCA) with the environmental variables and soil cover by life forms in tree intact forest fragments and tree logged fragments. Factor 1 explains $26.5 \%$ and Factor $214.0 \%$ of variance. A. Factor loadings of environmental variables and soil cover. B. Factor scores of sample units ( $\mathrm{N}=40$ sample units per forest fragment)

Although herbaceous-shrub vegetation was also linked to feces density and cattle trails (Fig. 1a), there were no indications of causality between them. Trees of up to $1 \mathrm{~m}$ in height covered $10-25 \%$ (median) of soil in the studied fragments (Fig. 3), but they were not related to the studied environmental variables or to other life forms (Fig. 1a).

Population structures - The number and proportion of individuals in the development classes are shown in Table 2. Adult individuals of Myracrodruon and Tabebuia had higher densities in intact than in logged fragments. About 33-55 adults/ha of Myracrodruon were found in the intact fragments, while logged fragments had 4-16 adults/ha. Tabebuia had 14-25 adults/ha in intact and 1-15 adults/ha in logged fragments. Astronium had low density of adults (8-13 adults/ha) in intact fragments, similar to logged fragments. 

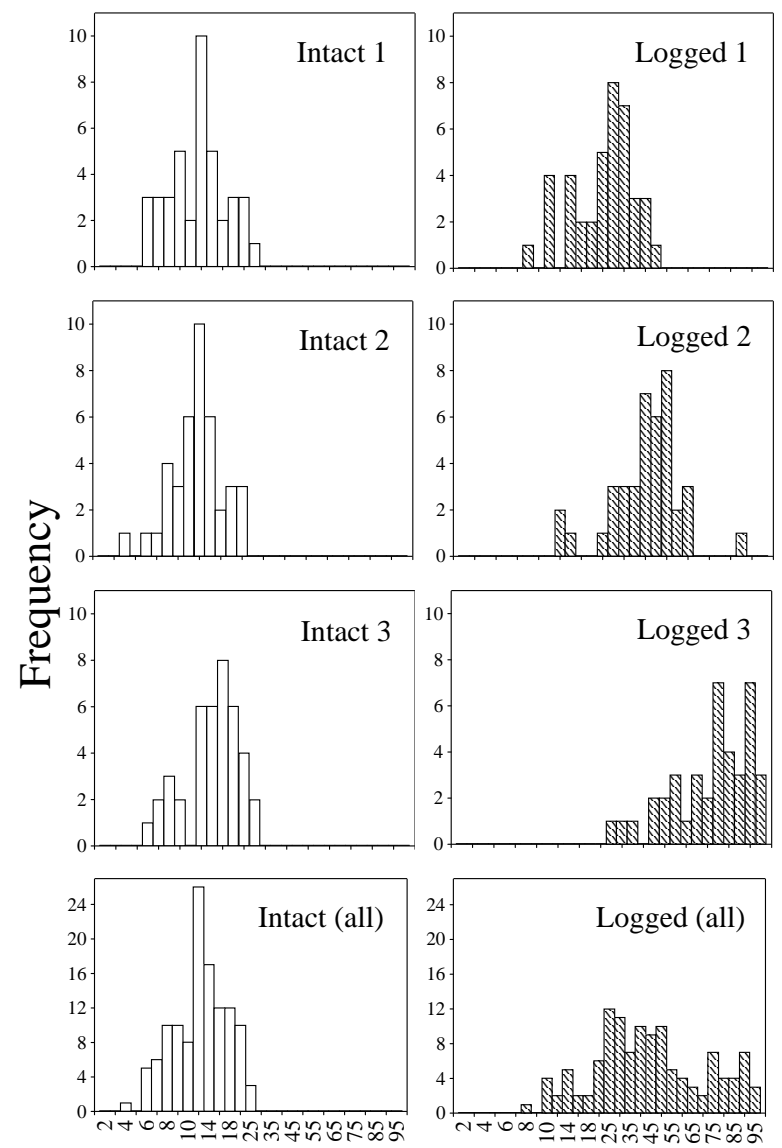

Canopy openness (\%)

Figure 2 - Frequency of canopy openness classes in tree intact forest fragments and their combination (Intact (all)), and tree logged forest fragments and their combination (Logged (all)). $\mathrm{N}=40$ per fragment. Note that the size of the classes is not the same

The seedlings of Tabebuia, Myracrodruon and Astronium were relatively abundant. For these species, which produced copious small winddispersed seeds, seedling density was roughly proportional to adult density, although there were proportionally more seedlings of Astronium related to adults in Intact and of Myracrodruon in L3.

The proportion of saplings and juveniles of Myracrodruon in logged fragments was higher than in Intact, with sapling density being 2.5 times higher in L3 that in any other fragment. Tabebuia saplings and juveniles contributed more to population size in L3 and L2 than did in Intact, but in L3 the proportion and density was higher than in any other fragment. Logged 1 had a high proportion of juveniles, but a smaller proportion of saplings of Tabebuia. Astronium had high juvenile density in L3, but saplings were not sampled in any fragment, and juveniles were proportionally more abundant in L2 and L3 than in Intact.

Population structures of Cavanillesia, Eugenia and Swartzia were not different between logged and Intact. They occurred in low densities even in intact fragments. Seedlings of these species were not sampled in most fragments. 
Total

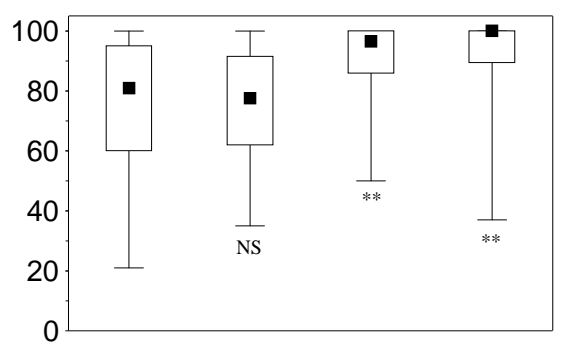

Trees

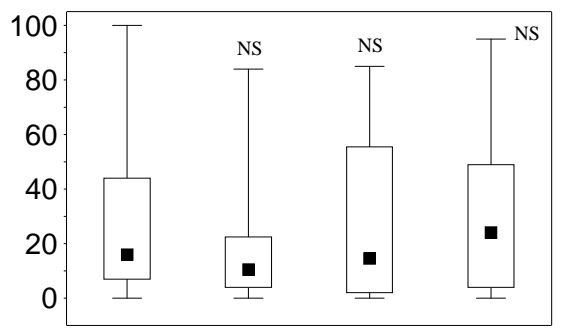

Lianas
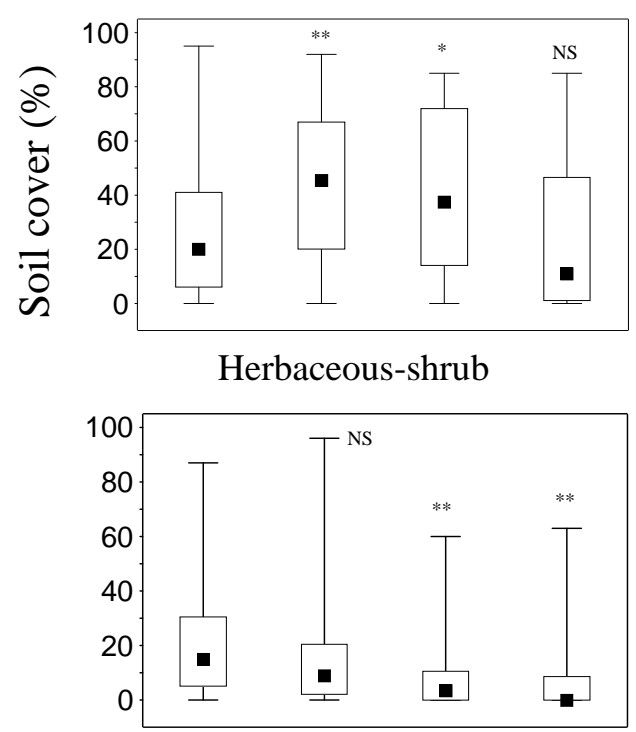

Invasive herbs

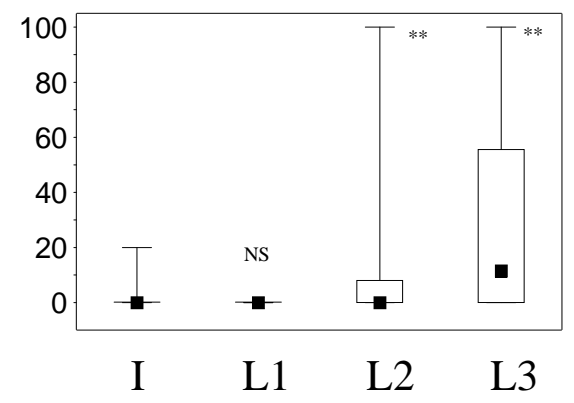

Figure 3 - Soil cover percentage by life forms and total soil cover in Intact (I) forest fragments (combination of tree intact forest fragments) and tree logged forest fragments (L1, L2 and L3). Maximum and minimum, quartiles and median are shown. Significant differences between each logged fragment and Intact are indicated. $\mathrm{N}=40$ per fragment and $\mathrm{N}=160$ in Intact 


\section{DISCUSSION}

Environmental variables - Canopy openness is the variable best describing logging and fire disturbance in the fragments, and can be particularly useful when there is no information about the frequency and the intensity of site management. The weak relationship between the number of stumps and canopy openness is probably due to: (1) different logging ages among fragments that resulted in different rates of stump decomposition; (2) the fire that occurred in L3, which probably caused high canopy openness and possibly eliminated some of the present stumps present. Therefore, the number of stumps does not seem to be a good indicator of the logging intensity in the studied forests. However, in tropical flooded forests of Costa Rica recently logged, the number of stumps is strongly correlated with canopy openness (Webb, 1997).

Canopy openness found in L1, L2 and L3 were higher than logged forests of other regions, even considering only canopy openness of gaps. For instance, $80 \%$ of $4-11$ year-old gaps generated by selective logging in semi-deciduous forests of Mexico had 20-40\% of canopy openness (Dickinson et al., 2000). The canopy openness in gaps recently formed by conventional selective logging was approximately $29 \%$ in the eastern Brazilian Amazon (Pereira et al., 2002) and approximately $12 \%$ in the humid subtropical forests of Belize (Whitman et al., 1997). The reason why canopy openness was higher in the logged dry forests of this study is not clear. Many interacting variables were not surveyed in this study, as logging procedures and forest structure (e.g. canopy height, tree density, understory structure and liana density connecting trees). Independent of the reason, the high canopy openness changes radically forest microclimate (Uhl and Vieira, 1989; Veríssimo et al., 1992; Webb, 1997), which can affect proportionally the community composition (Bawa and Seidler 1998). The amount of cattle feces and trials depends on the cattle density and the time they spend in the fragments, which varies between areas and years, following the farmer's decisions. The high variation of feces density in the fragments indicates that animals use them in clumps. In fact, cattle is associated to shade, where the stratum up to $1 \mathrm{~m}$ height is less dense. Places with dense shrub vegetation, such as liana tangles, limit the movement of animals (Valiente-Banuet et al., 1991).

Soil cover - There was considerable soil cover in all the fragments, so that even the smallest total soil cover was about $80 \%$ in Intact. These results agreed with findings from deciduous forests of Bolivia, where the total soil cover (up to $2 \mathrm{~m}$ in height) reached $81 \%$ in unlogged areas and 9599\% in logged areas (Frederiksen and Mostacedo, 2000), suggesting that in tropical deciduous forests high herbaceous and shrub cover prevented tree regeneration, independent of canopy disturbance.

High soil cover by lianas is associated with elevated light levels (Schnitzer et al., 2000; Alvira et al., 2004). This statement was confirmed in the studied fragments. However, in L3, fire might have eliminated the lianas, favoring invasive herbs instead. In Bolivian dry forests, three years after a forest fire, the density of lianas was lower than in an unburned forest (Gould, 1999), although in the more humid forests, lianas have spread promptly after fire occurrence (Pinard et al., 1999a). Invasive herbs were very frequent in pastures surrounding the fragments, and were closely related to completely open areas, dominating the herbaceous layer in patches where the canopy was fully open in L3.

Population structure - The low density of seedlings and saplings of Cavanillesia, Eugenia and Swartzia suggested high mortality between seed dispersal and early seedling development. In fact, seed predation of these species reached $65-100 \%$, part of them eaten by cattle (Vieira and Scariot, 2006b). Once seeds were protected from vertebrates, germination increased by $75 \%$. Seedling density of Astronium, Myracrodruon and Tabebuia is generally related to adult density, although this is not the only factor determining seedling density. Mature individuals occurring in the adjacent forest fragments and pastures produce a high number of small wind-dispersed seeds, which can reach the logged fragments. Seeds of Tabebuia and Astronium have high germination rates under different canopy openness and do not suffer high predation (Vieira and Scariot, 2006b). 
Table 2 - Stem density (individuals/ha) of six tree species in three intact (I) and three logged (L) forest fragments in the Paranã river basin, GO, Brazil. The Intact category is an average of the Intact fragments. The percentages of individuals in the development classes to the total population are shown. Significant differences in the proportion of development classes between each logged forest fragment and Intact are indicated (*).

\begin{tabular}{|c|c|c|c|c|c|c|c|c|}
\hline \multicolumn{9}{|c|}{ a) Myracrodruon urundeuva } \\
\hline Fragment & \multicolumn{2}{|c|}{ Seedling } & \multicolumn{2}{|c|}{ Sapling } & \multicolumn{2}{|c|}{ Juvenile } & \multicolumn{2}{|c|}{ Adult } \\
\hline I 1 & \multicolumn{2}{|c|}{875} & \multicolumn{2}{|c|}{63} & \multicolumn{2}{|c|}{200} & \multicolumn{2}{|c|}{43} \\
\hline I 2 & \multicolumn{2}{|c|}{63} & \multicolumn{2}{|c|}{125} & \multicolumn{2}{|c|}{100} & \multicolumn{2}{|c|}{33} \\
\hline I 3 & \multicolumn{2}{|c|}{63} & \multicolumn{2}{|c|}{250} & \multicolumn{2}{|c|}{300} & \multicolumn{2}{|c|}{55} \\
\hline Intact & 333 & $45 \%$ & 146 & $20 \%$ & 200 & $27 \%$ & 44 & $6 \%$ \\
\hline $\mathrm{L} 1 *$ & 63 & $9 \%$ & 250 & $34 \%$ & 400 & $55 \%$ & 4 & $1 \%$ \\
\hline $\mathrm{L} 2 *$ & 125 & $9 \%$ & 313 & $21 \%$ & 1000 & $68 \%$ & 16 & $1 \%$ \\
\hline$\underline{\mathrm{L}} 3 *$ & 438 & $22 \%$ & 813 & $41 \%$ & 700 & $36 \%$ & 9 & $<1 \%$ \\
\hline \multicolumn{9}{|c|}{ b) Tabebuia impetiginosa } \\
\hline I 1 & \multicolumn{2}{|c|}{115750} & & & & & & 17 \\
\hline I 2 & 1459 & & & 3 & & ) & & 14 \\
\hline I 3 & 4283 & & & & & 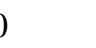 & & 25 \\
\hline Intact & 230000 & $100 \%$ & 438 & $<1 \%$ & 67 & $<1 \%$ & 19 & $<1 \%$ \\
\hline $\mathrm{L} 1 *$ & 308125 & $100 \%$ & 188 & $<1 \%$ & 200 & $<1 \%$ & 15 & $<1 \%$ \\
\hline $\mathrm{L} 2 *$ & 90500 & $98 \%$ & 625 & $1 \%$ & 1000 & $1 \%$ & 6 & $<1 \%$ \\
\hline$\underline{\mathrm{L}} 3 *$ & 21500 & $81 \%$ & 1688 & $6 \%$ & 3300 & $12 \%$ & 1 & $<1 \%$ \\
\hline c) Astronium frax & & & & & & & & \\
\hline I 1 & 38 & & & 0 & & & & 8 \\
\hline I 2 & 19 & & & 0 & & & & 6 \\
\hline I 3 & 55 & & & 0 & & & & 13 \\
\hline Intact & 3792 & $97 \%$ & 0 & $0 \%$ & 100 & $3 \%$ & 9 & $<1 \%$ \\
\hline $\mathrm{L} 1 *$ & 500 & $98 \%$ & 0 & $0 \%$ & 0 & $0 \%$ & 4 & $1 \%$ \\
\hline $\mathrm{L} 2 *$ & 813 & $87 \%$ & 0 & $0 \%$ & 100 & $11 \%$ & 11 & $1 \%$ \\
\hline $\mathrm{L} 3 *$ & 63 & $8 \%$ & 0 & $0 \%$ & 700 & $91 \%$ & 2 & $<1 \%$ \\
\hline d) Cavanillesia a & & & & & & & & \\
\hline I 1 & & & & 0 & 0 & & & 4 \\
\hline I 2 & & & & & 1 & & & 4 \\
\hline I 3 & 6 & & & & 3 & & & 3 \\
\hline Intact & 21 & $9 \%$ & 200 & $87 \%$ & 1 & $<1 \%$ & 7 & $3 \%$ \\
\hline L 1 & 0 & $0 \%$ & 200 & $98 \%$ & 2 & $1 \%$ & 3 & $1 \%$ \\
\hline L 2 & 0 & $0 \%$ & 0 & $0 \%$ & 0 & $0 \%$ & 1 & $100 \%$ \\
\hline L 3 & 0 & $0 \%$ & 100 & $97 \%$ & 0 & $0 \%$ & 3 & $3 \%$ \\
\hline e) Eugenia dysent & & & & & & & & \\
\hline I 1 & & & & 0 & 2 & & & 0 \\
\hline I 2 & ( & & & ) & & & & 0 \\
\hline I 3 & & & & & 8 & & & 0 \\
\hline Intact & 0 & $0 \%$ & 21 & $39 \%$ & 33 & $61 \%$ & 0 & $0 \%$ \\
\hline L 1 & 63 & $16 \%$ & 250 & $65 \%$ & 70 & $18 \%$ & 0 & $0 \%$ \\
\hline L 2 & 0 & $0 \%$ & 188 & $76 \%$ & 60 & $24 \%$ & 0 & $0 \%$ \\
\hline L 3 & 0 & $0 \%$ & 125 & $93 \%$ & 10 & $7 \%$ & 0 & $0 \%$ \\
\hline f) Swartzia multij & & & & & & & & \\
\hline I 1 & & 0 & & & 0 & & & 3 \\
\hline I 2 & & o & & & 0 & & & 1 \\
\hline I 3 & & 0 & & & 0 & & & 4 \\
\hline Intact & 0 & $0 \%$ & 104 & $97 \%$ & 0 & $0 \%$ & 3 & $3 \%$ \\
\hline L 1 & 0 & $0 \%$ & 63 & $64 \%$ & 30 & $30 \%$ & 3 & $3 \%$ \\
\hline L 2 & 0 & $0 \%$ & 250 & $100 \%$ & 0 & $0 \%$ & 1 & $<1 \%$ \\
\hline $\mathrm{L} 3^{\mathrm{a}}$ & 0 & $0 \%$ & 0 & $0 \%$ & 0 & $0 \%$ & 0 & $0 \%$ \\
\hline
\end{tabular}

${ }^{\text {a }}$ Statistical test not run because no individual was sampled in the forest fragment. 
The density of Astronium and Tabebuia juveniles, as well as the density of Tabebuia and Myracrodruon saplings, might have increased in L3 because of the fast growth of smaller sized individuals favored by canopy openness, once these species are light demanding (Pinard et al., 1999b). Although there were many canopy gaps available for the regeneration of shade-intolerant species in L1, L2 and L3, the high liana cover in L1 and L2 might limit regeneration, as observed in tropical deciduous forests in Bolivia (Frederiksen and Mostacedo, 2000; Frederiksen et al., 2000). Lianas can dominate canopy gaps and prevent succession for years even in tropical moist forests (Babweterra et al., 2000; Schnitzer et al., 2000; Tabanez and Viana, 2000). Lianas differ from invasive herbs in competitive ability because: (1) they climb seedling or juvenile tree stems (Putz, 1991; Alvira et al., 2004), (2) they are perennial, while the sampled invaders only occur in the rainy season, and (3) they reduce the amount of light that reaches the herbaceous stratum.

Implications for management and conservation The evaluation of threat to a species population must take into account the seed dispersal, abundance of recruits, growth rate, sprouting capacity after felling or damage, resistance to fire, geographical range and abundance of adults (Martini et al., 1994). Large-seed species, which include Eugenia, Swartzia and Cavanillesia, have low seedling densities. Cattle eat many of the seeds, especially those of Cavanillesia and Swartzia (Vieira and Scariot, 2006b). The association of cattle with areas of closed canopy, where the herbaceous layer is less dense, suggests that in such places the populations of these species are suffering more impact than where herbaceous and shrub cover is dense. In fact, seeds of these species were less removed under liana tangles (colonizing gaps) than in closed canopy sites (Vieira and Scariot, 2006b). Therefore, logged forests, with high number of gaps and dense herbaceous layer have more escape sites for large seeds. On the other hand, in very disturbed forests with scarce resources and poor vertical structure, the absence of efficient seed dispersers can compromise the regeneration of species (Bawa and Seidler, 1998), such as Eugenia and Swartzia in this study. While the effects of logging on the fauna in these forests are unknown, there is generally increased abundance and decreased diversity of primate and rodent species in logged tropical forests (Bawa and Seidler, 1998).

Astronium, Myracrodruon and Tabebuia have a high capacity for production, dispersal and, at least for Astronium and Tabebuia, also germination in these forests (Vieira and Scariot, 2006b). These are typically heliophitic species (Lorenzi, 1992; for Myracrodruon and Tabebuia see Pinard et al., 1999b). Roots of Tabebuia (Pinard et al., 1999b), Myracrodruon and Astronium are also known for their great ability to resprout (Salomão and Leite, 1993; Pinard et al., 1999b; Vieira et al., 2006). These species can present high regeneration rates in logged forests, since lianas do not cover the soil excessively. In dry forest fragments of the Paranã river basin, where (1) liana tangles are escape sites for seeds (Vieira and Scariot, 2006b), (2) sapling and juvenile abundance is low (this study) and (3) lianas are expected to recover gaps rapidly after cut treatments (Alvira et al., 2004; Pariona et al., 2003; Schnitzer et al., 2004), it is recommend to clean the competing vegetation around tree sapling or juvenile, instead of eliminating every liana tangle in gaps.

\section{ACKNOWLEDGEMENTS}

We thank W. Hoffman, E. Bruna, R. P. Henriques, A. C. Sevilha, A. B. Sampaio, P. C. Bueno, E. S. Guarino and M. B. Medeiros for the comments and criticisms at different stages of the project, $\mathrm{C}$. Cordeiro for statistical advice, the brothers Edson, Lirio and Cláudio Melo for the help with field work and landowners for permission to study their forests. D. L. M. Vieira had a CNPq master scholarship. Pronabio / Probio / GEF / MMA, CNPq and FDG funded this study.

\section{RESUMO}

As estruturas populacionais de seis espécies de árvores foram estudadas em três fragmentos de floresta estacional decidual intactos e três fragmentos impactados pela exploração seletiva de madeira no nordeste goiano. Quarenta parcelas de $400 \mathrm{~m}^{2}$ foram estabelecidas em cada fragmento para a amostragem de populações, número de tocos, fezes de gado, troncos queimados e abertura de dossel. A cobertura do solo por formas de vida foi estimada em sub-parcelas de $1 \mathrm{~m}^{2}$. Lianas foram 
mais abundantes em fragmentos com perturbação intermediária, enquanto herbáceas invasoras no fragmento mais perturbado. Cavanillesia arborea, Eugenia dysenterica e Swartzia multijuga ocorreram em densidades muito baixas em todos os fragmentos e plântulas foram praticamente ausentes, o que pode ameaçar o futuro de suas populações. Myracrodruon urundeuva, Tabebuia impetiginosa e Astronium fraxinifolium, as espécies mais exploradas da região, tiveram alta densidade de plântulas em todos os fragmentos. Entretanto, a maior densidade de plântulas estabelecidas ( $>1$ ano) e juvenis ocorreu no fragmento mais perturbado.

\section{REFERENCES}

Alvira, D.; Putz, F. E. and Fredericksen, T. S. (2004), Liana loads and post-logging liana densities after liana cutting in a lowland forest in Bolivia. For. Ecol. Manage., 190, 73-86.

Andahur, J. P. (2001), Florestas e questões de gestão ambiental na bacia do rio Paranã. MSc Thesis, Departamento de Engenharia Florestal, Universidade de Brasília, Brasília, Brazil.

Babweteera, F.; Plumptre, A. and Obua, J. (2000), Effect of gap size and age on climber abundance and diversity in Budongo Forest Reserve, Uganda. Afr. J. Ecol., 38, 230-237.

Bawa, K. S. and Seidler, R. (1998), Natural forest management and conservation of biodiversity in tropical forests. Conserv. Biol., 12, 46-55.

Ceccon, E.; Huante, P. and Rincón, E. (2006), Abiotic Factors Influencing Tropical Dry Forests Regeneration. Braz. Arch. Biol. Technol., 49, 305312.

Chapman, C. A. and Chapman, L. J. (1997), Forest regeneration in logged and unlogged forests of Kibale National Park, Uganda. Biotropica, 29, 396-412.

Chazdon, R. L. (1998), Ecology - Tropical forests - Log 'em or leave 'em? Science, 281, 1295-1296.

Dickinson, M. B.; Whigham, D. F. and Hermann, S. M. (2000), Tree regeneration in felling and natural treefall disturbances in a semideciduous tropical forest in Mexico. For. Ecol. Manage., 134, 137-151.

EMBRAPA 1999, Sistema brasileiro de classificação de solos. Embrapa Produção de informação, Brasília; Embrapa Solos, Rio de Janeiro.

Fredericksen, T. S. and Mostacedo, B. (2000), Regeneration of timber species following selection logging in a Bolivian tropical dry forest. For. Ecol. Manage., 131, 47-55.
Fredericksen, T. S. and Pariona, W. (2002), Effect of skidder disturbance on commercial tree regeneration in logging gaps in a Bolivian tropical forest. For. Ecol. Manage., 171, 223-230.

Fredericksen, T. S.; Justiniano, M. J.; Mostacedo, B.; Kennard, D. and Mcdonald, L. (2000), Comparative regeneration ecology of three leguminous timber species in a Bolivian tropical dry forest. New For., 20, 45-64.

Gould, K. (1999), Regeneracion posterior al fuego en los bosques tropicales bolivianos: implicaciones para el uso de quemas controladas. Documento Técnico \#89, Proyeto Bolfor, Bolívia.

Guariguata, M. R. and Pinard, M. A. (1998), Ecological knowledge of regeneration from seed in neotropical forest trees: Implications for natural forest management. For. Ecol. Manage., 112, 87-99.

IBGE (1995), Zoneamento geoambiental $e$ agroecológico do estado de Goiás: região nordeste. Série Estudos e Pesquisas em Geociências, IBGE / Divisão de Geociências do Centro-Oeste, Rio de Janeiro.

Jackson, S. M.; Fredericksen, T. S. and Malcolm, J. R. (2002), Area disturbed and residual stand damage following logging in a Bolivian tropical forest. For. Ecol. Manage., 166, 271-283.

Janzen, D. H. (1988), Tropical dry forest: the most endangered major tropical ecosystem. In-Biodiversity, ed. E. O. Wilson. National Academy Press, Washington, pp- 130-137.

Johns, A. D. (1988), Effects of Selective Timber Extraction on Rain-Forest Structure and Composition and Some Consequences for Frugivores and Folivores. Biotropica, 20, 31-37.

Kammesheidt, L. (1998), Stand structure and spatial pattern of commercial species in logged and unlogged Venezuelan forest. For. Ecol. Manage., 109, 163174.

Khurana, E. and Singh, J. S. (2001), Ecology of seed and seedling growth for conservation and restoration of tropical dry forest : a review. Environ. Conserv., 28, 39-52.

Kent, M. and Coker, P. (1994), Vegetation description and analysis: a practical approach. John Wiley and Sons, Chichester.

Kuusipalo, J.; Jafarsidik, Y.; Adjers, G. and Tuomela, K. (1996), Population dynamics of tree seedlings in a mixed dipterocarp rainforest before and after logging and crown liberation. For. Ecol. Manage., 81, 85-94.

Lemmon, P. E. (1957), A new instrument for measuring forest overstory density. J. Fo.r, 55, 667-668.

Lorenzi, H. (1992), Árvores brasileiras: manual de identificação e cultivo de plantas arbóreas nativas do Brasil. Editora Plantarum, Nova Odessa.

Martini, A. M. Z.; Rosa, N. D. and Uhl, C. (1994), An Attempt to Predict Which Amazonian Tree Species May Be Threatened by Logging Activities. Environ. Conserv., 21, 152-162. 
Pariona, W.; Fredericksen, T. S. and Licona, J. C. (2003), Natural regeneration and liberation of timber species in logging gaps in two Bolivian tropical forests. For. Ecol. Manage., 181, 313-322.

Pereira, R.; Zweede, J.; Asner, G. P. and Keller, M. (2002), Forest canopy damage and recovery in reduced-impact and conventional selective logging in eastern Para, Brazil. For. Ecol. Manage., 168, 77-89.

Pinard, M. A. and Putz, F. E. (1996), Retaining forest biomass by reducing logging damage. Biotropica, 28, 278-295.

Pinard, M. A.; Lutz, F. E. and Licona, J. C. (1999a), Tree mortality and vine proliferation following a wildfire in a subhumid tropical forest in eastern Bolivia. For. Ecol. Manage., 116, 247-252.

Pinard, M. A.; Putz, F. E.; Rumiz, D.; Guzman, R. and Jardim, A. (1999b), Ecological characterization of tree species for guiding forest management decisions in seasonally dry forests in Lomerio, Bolivia. For. Ecol. Manage., 113, 201-213.

Putz, J. (1991), Silvicultural effects of lianas. In-The biology of vines, eds. F. Putz and H. Mooney. Cambridge University Press, Cambridge, pp.73-98.

Ratter, J. A. (1992), Transitions between cerrado and forest vegetation in Brasil. In-Nature and dynamics of forest-savanna boundaries, eds. P. A. Furley; J. Proctor and J. A. Ratter. Chapman and Hall, London, pp.51-76.

Relva, M. A. and Veblen, T. T. (1998), Impacts of introduced large herbivores on Austrocedrus chilensis forests in northern Patagonia, Argentina. For. Ecol. Manage., 108, 27-40.

Salomão, A. N.; Leite, A. M. C. (1993), Comportamento de regenerantes de Astronium urundeuva (Fr. All.) Engler em área sob ação antrópica. Acta Bot. Bras., 6, 85-96.

Sanchez-Azofeifa, G. A.; Kalacska, M.; Quesada, M.; Calvo-Alvarado, J. C.; Nassar J. M. and Rodríguez, J. P. (2005), Need for integrated research for a sustainable future in tropical dry forests. Cons. Biol., 19, 285-286.

SAS Institute Inc. (1999). SAS/STAT user's guide, Version 8. SAS Institute Inc, Cary.

Scariot, A. and Sevilha, A. C. (2000), Diversidade, estrutura e manejo de florestas deciduais e as estratégias para a conservação. In-Tópicos atuais em botânica: palestras convidadas do 51 o congresso nacional de botânica, eds. T. B. Cavalcanti and B. M. T. Walter. Embrapa Recursos Genéticos e Biotecnologia, Brasília, pp.183-188.

Scariot, A. and Sevilha, A. C. (2005), Biodiversidade, estrutura e conservação de florestas estacionais deciduais no Cerrado. In-Ecologia, biodiversidade $e$ conservação do Cerrado, eds. A. Scariot; J. C. SousaSilva; J. M. Felfili. Ministério do Meio Ambiente, Brasília, pp.121-139.
Schnitzer, S. A.; Dalling, J. W. and Carson, W. P. (2000), The impact of lianas on tree regeneration in tropical forest canopy gaps: evidence for an alternative pathway of gap-phase regeneration. $J$. Ecol., 88, 655-666.

Schnitzer, S. A.; Parren, M. P. E. and Bongers, F. (2004), Recruitment of lianas into logging gaps and the effects of pre-harvest climber cutting in a lowland forest in Cameroon. For. Ecol. Manage., 190, 87-98.

Siegel, S. (1975), Estatística não-paramétrica para as ciências do comportamento. McGraw-Hill do Brasil, Ltda., São Paulo.

Silva, L. Á. and Scariot, A. (2003), Estrutura da comunidade arbórea em uma floresta estacional decidual em afloramento calcário (Fazenda São José, São Domingos - GO, bacia do rio Paranã). Acta Bot. Bras., 17, 305-313.

Silva, L. Á. and Scariot, A. (2004a), Composição e estrutura da comunidade arbórea de uma floresta estacional decidual sobre afloramento calcário no Brasil Central. Rev. Árvore 28, 61-67.

Silva, L. Á. and Scariot, A. (2004b), Composição e estrutura da comunidade arbórea de uma floresta estacional decidual sobre afloramento calcário no Brasil Central. Rev. Árvore 28, 69-75.

Statsoft, Inc. (2000). STATISTICA for Windows. Statsoft, Inc., Tulsa.

Tabachnick, B. G. and Fidell, L. S. (2001), Using multivariate statistics. Allyn and Bacon, Boston.

Tabanez, A. A. J. and Viana, V. M. (2000), Patch structure within Brazilian Atlantic forest fragments and implications for conservation. Biotropica, 32, 925-933.

Uhl, C. and Vieira, I. C. G. (1989), Ecological Impacts of Selective Logging in the Brazilian Amazon - a Case-Study from the Paragominas Region of the State of Para. Biotropica, 21, 98-106.

Valiente-Banuet, A.; Bolongarocrevenna, A.; Briones, O.; Ezcurra, E.; Rosas, M.; Nunez, H.; Barnard, G. and Vazquez, E. (1991), Spatial Relationships between Cacti and Nurse Shrubs in a Semiarid Environment in Central Mexico. J. Veg. Sci., 2, 1520.

Verissimo, A.; Barreto, P.; Mattos, M.; Tarifa, R. and Uhl, C. (1992), Logging Impacts and Prospects for Sustainable Forest Management in an Old Amazonian Frontier - the Case of Paragominas. For. Ecol. Manage., 55, 169-199.

Vieira, D. L. M.; Scariot, A. (2006a), Principles of natural regeneration of tropical dry forests for restoration. Rest. Ecol., 14, 11-20.

Vieira, D. L. M.; Scariot, A. (2006b), Effects of logging, liana tangles and pasture on seed fate of dry forest tree species in Central Brazil. For. Ecol. Manage., 230, 197-205. 
Vieira, D. L. M.; Scariot, A.; Sampaio, A. B. and Holl, K. D. (2006), Tropical dry-forest regeneration from root suckers in Central Brazil. J. Trop. Ecol., 22, 353357.

Webb, E. L. (1997), Canopy removal and residual stand damage during controlled selective logging in lowland swamp forest of northeast Costa Rica. For. Ecol. Manage., 95, 117-129.

Webb, E. L. (1998), Gap-phase regeneration in selectively logged lowland swamp forest, northeastern Costa Rica. J. Trop. Ecol., 14, 247-260.
Whitman, A. A.; Brokaw, N. V. L. and Hagan, J. M. (1997), Forest damage caused by selection logging of mahogany (Swietenia macrophylla) in northern Belize. For. Ecol. Manage., 92, 87-96.

Zar, J. H. (1999), Biostatistical analysis. Prentice Hall Inc., Englewood Cliffs.

Zelterman, D. (1999), Models for discrete data. Clarendon Press, New York.
Received: March 04, 2006; Revised: August 10, 2006; Accepted: August 03, 2007. 
PÁGINA

EM

BRANCO 